\title{
STABILITY OF THE ISOMERS OF DIHYDROTHIAMINE
}

\author{
CHIKATARO KAWASAKI AND KOZO OKADA ${ }^{1}$ \\ School of Pharmacy, Osaka University, Toyonaka
}

(Received July 2, 1964)

In order to investigate the chemical form of $\mathrm{TH}_{2}{ }^{2}$ in aqueous solution it was demonstrated in the previous paper (1) that the $\psi$-form was the stablest of three isomers of $\mathrm{TH}_{2}$ by comparing the stability of the aqueous dilute solution of $\mathrm{TH}_{2}$. In this paper the stability of the $\psi$-form of $\mathrm{TH}_{2}$ in aqueous solution is discussed from the standpoint of its change by some reagents.

\section{EXPERIMENTAL}

1. Time Course of the Change of $\mathrm{TH}_{2}$ in Aqueous Solution at Various pH Levels

The aqueous solution of $\psi$ - $\mathrm{TH}_{2}$ was left standing at various $\mathrm{pH}$ levels and the stability was successively investigated. $n$-Form of $\mathrm{TH}_{2}$ is dissolved in a small amount of $N / 10 \mathrm{HCl}$ and diluted with a suitable amount of water. It was neutralized with a dilute $\mathrm{NaOH}$ solution and water was added to make a $2.0 \mathrm{mg} / \mathrm{ml}$ solution, in which $\mathrm{TH}_{2}$ had been completely converted to $\psi$-form. $4 \mathrm{ml}$ of this solution was mixed with $1.5 \mathrm{ml}$ of the acid or $M / 10$ buffer solution and the whole covered with a stopper was incubated at $35^{\circ}$. After various time intervals an aliquot was taken and the amounts of $\mathrm{TH}_{2}$ and thiamine were determined by $\mathrm{FeCl}_{3}$ and $\mathrm{BrCN}$ method respectively. (2) As shown in Fig. 1, $\mathrm{TH}_{2}$ was relatively stable in a very weakly acidic to alkaline solution, and 70 to $80 \%$ of it remained unchanged even after 4 hours, whereas it was unstable in an acidic solution and was quickly degraded, about 3 to $9 \%$ being converted into thiamine. Besides, formation of triamine ${ }^{2}$ was found in the reaction mixture by paper chromatography. Since $\mathrm{TH}_{2}$ is so easily degraded in acid solution and a part of it is converted to thiamine by air oxidation, the change of $\mathrm{TH}_{2}$ in the weakly acid solution after adding hydrogen peroxide or cyanide was investigated.

\section{Effect of Hydrogen Peroxide on $\mathrm{TH}_{2}$}

Although $\mathrm{TH}_{2}$ was easily oxidized to thiamine by such oxidants, as $\mathrm{FeCl}_{3}$ both $n$ - or $\psi-\mathrm{TH}_{2}$ in acetic acid solution was relatively easily degraded to DAPm sulfate by hydrogen peroxide, and in neutral or alkaline solution no marked change was observed.

$n$ - or $\psi-\mathrm{TH}_{2}, 0.5 \mathrm{~g}$, was dissolved in $5 \mathrm{ml}$ of $50 \%$ acetic acid, $0.6 \mathrm{ml}$ of $30 \%$

1 川崎近太郎, 岡田幸蔵。

${ }^{2}$ Following abbreviations were used: $\mathrm{TH}_{2}$, dihydrothiamine; n, normal; $\psi$, pseudo; triamine, tris (2-methyl-4-amino-5-pyrimidylmethyl)-hexahydro-S-triazine; DAPm, 2-methyl-4-amino-5amino-methyl-pyrimidine. 


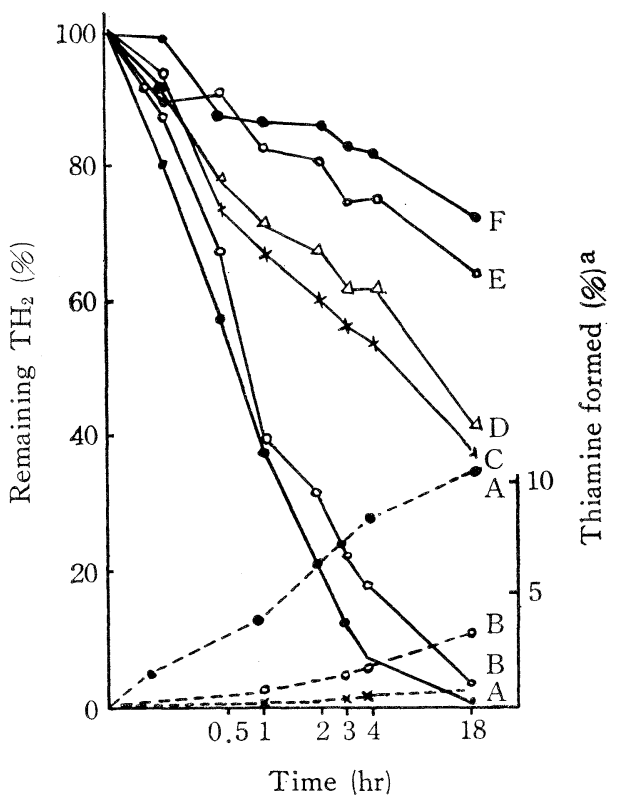

Fig. 1 Stability of $\mathrm{TH}_{2}$ Solution

A, $0.3 M \mathrm{HCl}$; B, $0.03 M \mathrm{HCl}$; C, $0.03 M \mathrm{CH}_{3} \mathrm{COOH}$; $\mathrm{D}, 0.03 \mathrm{M}$ acetate buffer, $\mathrm{pH} 3.2 ; \mathrm{E}, 0.03 \mathrm{M}$ phosphate buffer, pH 6.2; F, $0.03 M$ phosphate buffer, pH 8.4.

$a$ The amount of thiamine formed as estimated by $\mathrm{FeCl}_{3}$ was taken as $100 \%$.

-, remaining $\mathrm{TH}_{2} ; \cdots$, thiamine formed.

hydrogen peroxide was added, and after standing for 48 hours at room temperature $5 \mathrm{ml}$ of ethyl alcohol was added, whereby colorless needles were precipitated, yielding $0.2 \mathrm{~g}$. After recrystallization from diluted alcohol it decomposed at $265^{\circ}$, and the ultraviolet and infrared absorption spectra and elementary analyses were in good agreement with that of $\mathrm{DAP}_{\mathrm{m}}$ sulfate. Elementary analyses: Calculated for $\mathrm{C}_{6} \mathrm{H}_{10} \mathrm{~N}_{4} \cdot \mathrm{H}_{2} \mathrm{SO}_{4} \cdot 2 \mathrm{H}_{2} \mathrm{O}, \mathrm{C}, 26.46, \mathrm{H}, 5.92, \mathrm{~N}, 20.57, \mathrm{~S}, 11.84$ and crystal water, 12.23 . Found: C, 26.19, H, 5.84, N, 19.83, S, 11.83 and crystal water, 12.88.

\section{Effect of Cyanide on $\mathrm{TH}_{2}$}

$\mathrm{TH}_{2}$ is known to be converted to thiamine in some extent by air oxidation in the presence of hydrochloric acid or protein (3), and also in the presence of active carbon (4). Since $\mathrm{TH}_{2}$ has a property to be easily oxidized by air, it was assumed that $\mathrm{TH}_{2}$ might be stabilized in the presence of reductants such as potassium cyanide. However, cyanide was found to catalytically accelerate the air oxidation of $\mathrm{TH}_{2}$. The reaction mixtures containing $2.5 \mathrm{ml}$ of $\mathrm{TH}_{2}$ solution $(100 \mu \mathrm{g} / \mathrm{ml})$, $2 \mathrm{ml}$ of $M / 10$ acetate buffer $(\mathrm{pH} 4.5)$ and $1 \mathrm{ml}$ of $\mathrm{KCN}$ solution $(10 \mathrm{mg} / \mathrm{ml}, \mathrm{pH}$ 4.5), were left standing at room temperature, $37^{\circ}, 60^{\circ}$ and $80^{\circ}$, and the amount of thiamine formed was estimated. As shown in Fig. 2, about $9 \%$ thiamine was formed after the reaction at $37^{\circ}$ for 5 hours. In order to investigate the effect of $\mathrm{pH}$ on the reaction, acetate buffer in the reaction mixture was replaced by $N / 100$ 


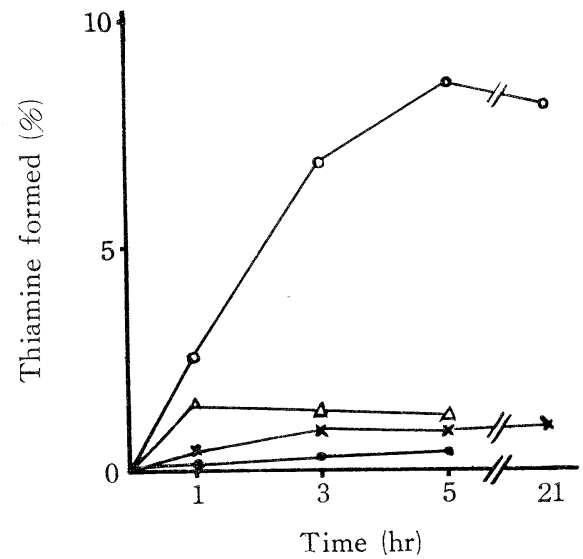

Fig. 2 Effect of Temperature and Time on Formation of Thiamine from $\mathrm{TH}_{2}$ by $\mathrm{KCN}$

$\mathrm{TH}_{2}$ equivalent to $113 \mu \mathrm{g}$ thiamine was added. $\circ, 37^{\circ} ; \times$, room temperature; $\bullet, 60^{\circ} ; \mathbf{\Delta}, 80^{\circ}$.

$\mathrm{HCl}(\mathrm{pH} 2)$ and $M / 10$ buffers (acetate for $\mathrm{pH} 3.5$ to 4.5 and phosphate for $\mathrm{pH} 5.5$ to 7.5), and the amounts of thiamine formed were compared. As given in Fig. 3,

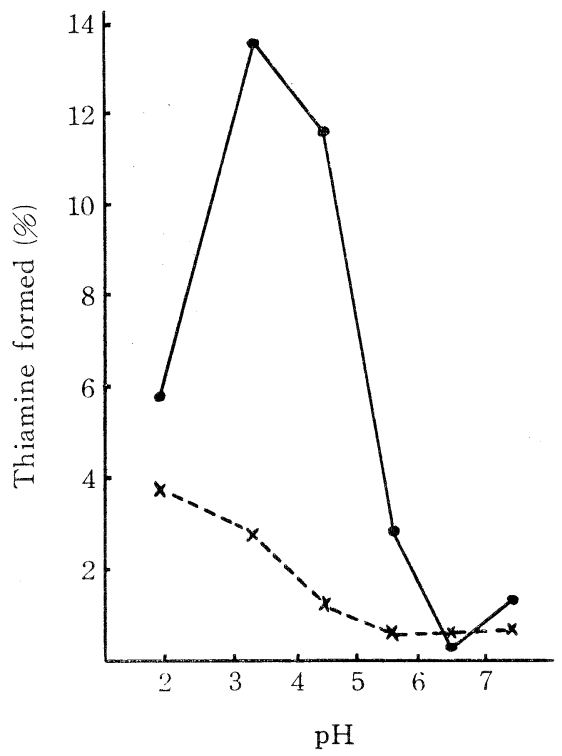

Fig. 3 Effect of $\mathrm{pH}$ on Formation of Thiamine from $\mathrm{TH}_{2}$ $\mathrm{TH}_{2}$ equivalent to $234 \mu \mathrm{g}$ thiamine was added.

- main experiment; $\times$, control (water was used in place of $\mathrm{KCN}$ solution)

thiamine formation increased in an acid solution below $\mathrm{pH} 4.5$, but after correction for the control values it showed the maximum value at $\mathrm{pH} 3.5$ to 4.5. As reported 
in the previous paper (1) $\mathrm{TH}_{2}$ is assumed to exist as a quaternary ammonium form in a weakly acid solution, which is easily partially oxidized by air to thiamine similarly to the case' in the presence of protein or active carbon. To ascertain these facts, the reaction mixture was placed in the Thunberg tube. The reaction mixture contained $1 \mathrm{ml}$ of $20 \mu \mathrm{g} / \mathrm{ml} \mathrm{TH}, 2 \mathrm{ml}$ of $100 \mathrm{mg} / \mathrm{ml} \mathrm{KCN}$ solution ( $\mathrm{pH}$ 4.5 ) and $2 \mathrm{ml}$ of $M / 10$ acetate buffer $(\mathrm{pH} 4.5)$. It was incubated after replacing the air by hydrogen, oxygen or nitrogen at $37^{\circ}$ for 20 hours and the thiamine formation was compared. As a control, similar experiment was carried out using water in place of $\mathrm{KCN}$ solution. As summarized in Table I, thiamine formation

TABLE I

Effect of Gas Phase

\begin{tabular}{lllll}
\hline \multirow{2}{*}{ Gas } & \multicolumn{4}{c}{ Thiamine formed } \\
\cline { 2 - 4 } & \multicolumn{3}{c}{ Main experiment } & \multicolumn{2}{c}{ Control } \\
\hline Hydrogen & $\mu g$ & $(\%)$ & $\mu g$ & $(\%)$ \\
Nitrogen & 3.0 & $(20.7)$ & $0.3(2.1)$ \\
Oxygen & 5.8 & $(40.0)$ & $0.3(2.1)$ \\
Air & 8.0 & $(55.2)$ & 0.5 & $(3.5)$ \\
& 6.8 & $(46.8)$ & 0.4 & $(2.8)$ \\
\hline
\end{tabular}

$\mathrm{TH}_{2}$ equivalent to $14.5 \mu \mathrm{g}$ thiamine was added

was accelerated in the presence of oxygen, whereas it was inhibited by nitrogen or hydrogen, showing the reaction to be oxidation by air.

To investigate the relationship between the amount of $\mathrm{KCN}$ and its action on $\mathrm{TH}_{2}$, various amounts of $\mathrm{KCN}$ were added to a constant amount of $\mathrm{TH}_{2}$ in Thunberg tubes and after oxygen-aeration for 2 minutes with ice-cooling, the tubes were incubated at $37^{\circ}$ for 5 hours. As shown in Table II, from $0.25 \mathrm{mg}$ $\mathrm{TH}_{2}$ scarcely any thiamine formation was detected after addition of $\mathrm{KCN}$ in

TABLE II

Thiamine Formation from $\mathrm{TH}_{2}$ by the Addition of Various Amounts of $K C N$

\begin{tabular}{|c|c|c|c|c|c|c|c|c|c|c|}
\hline & \multirow{2}{*}{ Experimental gas } & \multicolumn{9}{|c|}{$\mathrm{KCN}$ added $(m g)$} \\
\hline & & 0 & 0.01 & 0.1 & 1 & 2 & 4 & 8 & 10 & 100 \\
\hline \multirow{3}{*}{1} & \multicolumn{10}{|c|}{ Thiamine formed $(\mu g)$} \\
\hline & Oxygen aeration & $\begin{array}{c}4.8 \\
(1.8)^{a}\end{array}$ & $\begin{array}{c}6.2 \\
(2.3)\end{array}$ & $\begin{array}{l}5.7 \\
(2.1)\end{array}$ & $\begin{array}{c}6.6 \\
(2.4)\end{array}$ & & & & $\begin{array}{c}32.7 \\
(12.2)\end{array}$ & $\begin{array}{c}33.2 \\
(12.6)\end{array}$ \\
\hline & No aeration & $\begin{array}{c}1.3 \\
(0.5)^{a}\end{array}$ & $\begin{array}{c}0.6 \\
(0.2)\end{array}$ & $\begin{array}{l}1.1 \\
(0.4)\end{array}$ & $\begin{array}{c}3.0 \\
(1.1)\end{array}$ & & & & $\begin{array}{c}3.5 \\
(1.3)\end{array}$ & $\begin{array}{c}8.4 \\
(3.1)\end{array}$ \\
\hline 2 & Oxygen aeration & $\begin{array}{l}3.9 \\
(1.8)^{a}\end{array}$ & & & & $\begin{array}{c}3.7 \\
(1.7)\end{array}$ & $\begin{array}{c}6.0 \\
(2.8)\end{array}$ & $\begin{array}{c}7.1 \\
(3.3)\end{array}$ & $\begin{array}{l}18.0 \\
(8.4)\end{array}$ & $\begin{array}{l}13.2 \\
(6.2)\end{array}$ \\
\hline
\end{tabular}

$a$ The amount of thiamine formed by oxidation with $\mathrm{FeCl}_{3}$ from $\mathrm{TH}_{2}$ (Exp. 1, 270 $\mu \mathrm{g}$, Exp. 2, $214 \mu \mathrm{g})$ was expressed as $100 \%$.

Reaction mixture, $2.5 \mathrm{ml}$ of $\mathrm{n}-\mathrm{TH}_{2}, 1.0 \mathrm{ml}$ of $\mathrm{KCN}$ and $2.0 \mathrm{ml}$ of acetate buffer (pH 4.5).

amount less than $2 \mathrm{mg}$. With the increase of the amount of $\mathrm{KCN}$ thiamine formation rose gradually, reached to the constant value after addition of 8 to 
$10 \mathrm{mg} \mathrm{KCN}$, and no more increase was observed by further addition of $\mathrm{KCN}$. These results show that $\mathrm{KCN}$ at higher than a certain level is needed for thiamine formation. Under the above condition at least 8 to $10 \mathrm{mg} \mathrm{KCN}$ was needed for 4 to $5 \mathrm{ml}$ of the reaction mixture. The change in thiamine formation with the increase of the amount of $\mathrm{TH}_{2}$ in the presence of $10 \mathrm{mg} \mathrm{KCN}$ showed, that with the increase of the amount of $\mathrm{TH}_{2}$, the percentage formation of thiamine was reduced, as shown in Table III, and the amount of thiamine production was

TABLE III

Effect of Various Amounts of $\mathrm{TH}_{2}$ on the Formation of Thiamine and the Change in Cyanide

\begin{tabular}{|c|c|c|c|c|c|c|}
\hline \multirow{2}{*}{\multicolumn{2}{|c|}{ Time }} & & \multicolumn{4}{|c|}{$\mathrm{TH}_{2}$ added $(m g)$} \\
\hline & & & 5 & 10 & 15 & 20 \\
\hline \multirow[t]{3}{*}{$h r$} & \multirow{3}{*}{$\mathrm{B}_{1}$} & \multicolumn{5}{|c|}{ Thiamine formed $(\mu \mathrm{g})$} \\
\hline & & Main & $10.3(0.2)^{a}$ & $10.4(0.1)$ & $15.2(0.1)$ & $18.4(0.1)$ \\
\hline & & Control & $5.6(0.1)$ & $11.3(0.1)$ & $14.9(0.1)$ & $20.5(0.1)$ \\
\hline \multirow[t]{3}{*}{0} & \multirow{3}{*}{$\mathrm{CN}^{-}$} & & \multicolumn{3}{|c|}{ Remaining cyanide (per cent) } & \multirow{3}{*}{105} \\
\hline & & Main & \multirow[t]{2}{*}{89} & 88 & \multirow[t]{2}{*}{100} & \\
\hline & & Blank & & 100 & & \\
\hline \multirow{4}{*}{5} & \multirow{2}{*}{$\mathrm{B}_{1}$} & Main & $144.8(2.6)$ & $40.2(0.4)$ & $31.2(0.2)$ & $35.0(0.2)$ \\
\hline & & Control & $16.3(0.3)$ & $28.3(0.3)$ & $36.7(0.2)$ & $42.2(0.2)$ \\
\hline & \multirow{2}{*}{$\mathrm{CN}^{-}$} & Main & 89 & 86 & 93 & 91 \\
\hline & & Blank & & 98 & & \\
\hline \multirow{4}{*}{20} & \multirow{2}{*}{$\mathrm{B}_{1}$} & Main & $158.0(28)$ & $93.9(0.9)$ & $44.0(0.3)$ & $64.7(0.3)$ \\
\hline & & Control & $39.5(0.7)$ & $56.2(0.6)$ & $82.2(0.5)$ & $44.5(0.2)$ \\
\hline & \multirow{2}{*}{$\mathrm{CN}^{-}$} & Main & \multirow[t]{2}{*}{87} & - & & \\
\hline & & Blank & & 94 & & \\
\hline
\end{tabular}

a Thiamine formation in percent

Reaction mixture consisted of $0.5-2.0 \mathrm{ml} \mathrm{TH}$ (10 mg/ml), $0.8 \mathrm{ml} \mathrm{KCN}(10 \mathrm{mg} / \mathrm{ml}$, $\mathrm{pH} 4.5)$ and $1.6 \mathrm{ml}$ of $M / 10$ acetate buffer $(\mathrm{pH} 4.5)$ in a final volume of $4.4 \mathrm{ml}$, incubated at $37^{\circ}$ (main).

In the control, water was uesd in place of $\mathrm{KCN}$ in the reaction mixture.

In the blank, water was used in place of $\mathrm{TH}_{2}$ in the reaction mixture.

$\mathrm{CN}^{-}$was estimated by colorimeteric method (5) using mercuric thiocyanate and the value of the control at zoro time was used for reference.

far greater after addition of a small amount of $\mathrm{TH}_{2}$. As can be seen from Table II, at least 30 to 40 -fold amount of $\mathrm{KCN}$ is necessary for significant production of thiamine, from $0.25 \mathrm{mg} \mathrm{TH}_{2}$ and in the presence of $10 \mathrm{mg} \mathrm{KCN}$, with the rise of $\mathrm{TH}_{2}$ from 5 to $20 \mathrm{mg}$, thiamine formation decreases at higher levels of $\mathrm{TH}_{2}$, suggesting the need of much $\mathrm{KCN}$ in comparison with $\mathrm{TH}_{2}$. As shown in Table III, the oxidation of $\mathrm{TH}_{2}$ to thiamine is not directly dependent of the amount of cyanide.

These findings show that formation of thiamine by cyanide is marked in acetate buffer, $\mathrm{pH} 3.5-4.5$, and $\mathrm{KCN}$ is partially changed to $\mathrm{HCN}$. In the presence of $\mathrm{HCN}$ together with acetic acid and acetate, $\mathrm{TH}_{2}$ is possibly oxidized by air. As given in Table IV, $\mathrm{NaCN}$ and $\mathrm{KCNO}$ also showed a catalytic effect on the 
TABLE IV

The Effect of Cyanide, Cyanate and Rhodanate on the Oxidation of $\mathrm{TH}_{2}$

( ), thiamine formation, $\%$.

\begin{tabular}{ccccccrrr}
\hline \multirow{2}{*}{$\begin{array}{c}\text { Amount } \\
\text { added }\end{array}$} & \multicolumn{7}{c}{ Thiamine formed } \\
\cline { 2 - 7 } & $\begin{array}{c}\text { Without } \\
\text { addition }\end{array}$ & $\mathrm{NH}_{4} \mathrm{SCN}$ & $\mathrm{KSCN}$ & $\mathrm{KCNO}$ & $\mathrm{NaCN}$ & $\mathrm{KCN}$ & $\begin{array}{r}\mathrm{CH}_{2}\left(\mathrm{CN}^{-}\right. \\
\mathrm{COOC}_{2} \mathrm{H}_{5}\end{array}$ \\
\hline$m g$ & & 8.8 & 6.7 & $\mu g$ & & & \\
1 & & $(4.1)^{\boldsymbol{a}}$ & $(3.1)$ & $(3.1)$ & $(3.1)$ & $(3.0)$ & $(6.7)$ \\
& 6.9 & 5.8 & 4.7 & 19.4 & 30.5 & 29.5 & 8.9 \\
10 & $(3.2)$ & $(2.7)$ & $(2.2)$ & $(9.0)$ & $(14.4)$ & $(13.8)$ & $(4.1)$ \\
& & 0.5 & 6.7 & 25.9 & 25.1 & 35.0 & 0.2 \\
100 & & $(0.2)$ & $(3.1)$ & $(12.1)$ & $(11.7)$ & $(16.3)$ & $(0.1)$ \\
\hline
\end{tabular}

a Thiamine formation in per cent.

Reaction mixture containing $2.5 \mathrm{ml}$ of $\mathrm{TH}_{2}, 100 \mu \mathrm{g} / \mathrm{ml}, 1.0 \mathrm{ml}$ of the cyanide compounds of various concentrations and $2.0 \mathrm{ml}$ of $M / 10$ acetate buffer $(\mathrm{pH} 4.5$ ) was aerated with oxygen under ice cooling for 3 minutes, incubated at $37^{\circ}$ for $5 \mathrm{hr}$.

The amount of thiamine formed from $250 \mu \mathrm{g}$ of $\mathrm{TH}_{2}$ by $\mathrm{FeCl}_{3}$ was taken as $100 \%$.

oxidation of $\mathrm{TH}_{2}$, but thiocyanate was ineffctive. $\mathrm{CH}_{2}(\mathrm{CN}) \mathrm{COOC}_{2} \mathrm{H}_{5}$ accelerated the formation of thiamine with a small amount, whereas it inhibited the reaction with larger amounts similarly to that of $\mathrm{NH}_{4} \mathrm{SCN}$.

\section{DISCUSSION}

The findings that $\mathrm{TH}_{2}$ was converted to $\mathrm{DAP}_{\mathrm{m}}$ sulfate by oxidative degradation with hydrogen peroxide in a weakly acid solution and in the presence of cyanide it is patially converted to thiamine by air, and that it was most easily degraded by sulfite in a weakly acid solution as reported in the inprevious paper (1) suggest that $\mathrm{TH}_{2}$ may be present as a quarternary ammonium form in a weakly acid solution similarly to thiamine.

However, contrary to thiamine, quarternary ammonium salt of $\mathrm{TH}_{2}$ is labile and easily degraded, especially it is rapidly degraded by contact with protein or in animal body. Thiothiamine is known to form thiamine sulfate by oxidation with $\mathrm{H}_{2} \mathrm{O}_{2}$ in an acid solution, whereby the sulfur in position 2 of the thiazole moiety is removed and oxiaized. In $\mathrm{TH}_{2}$, the oxidation of the thiazole moiety is preceded by degradation and the mercapto compound simultaneously produced is oxidized to sulfuric acid and DAP sulfate is thus produced. The conversion of $\mathrm{TH}_{2}$ to thiamine in the presence of much cyanide may be compared with the finding that thiothiamine is oxidized to thiamine by the dissolved oxygen with simultaneous oxidation of $\mathrm{SO}_{3}^{-}(7)$. The acceleration of thiamine formation by cyanide is due to the oxidation by air dissolved in water. Supposing the saturation of $\mathrm{O}_{2}$ in water to be $30 \mathrm{ppm}$, and $\mathrm{TH}_{2}+\mathrm{O} \rightarrow$ thiamine $+\mathrm{H}_{2} \mathrm{O}, 5 \mathrm{ml}$ of the solution will produce about $3 \mathrm{mg}$ thiamine in the case of $100 \%$ yield. Considering that the percentage of thiamine formation is high at lower concentration of $\mathrm{TH}_{2}$ and the highest amount of thiamine formation was $0.15 \mathrm{mg}$ per $5 \mathrm{ml}$, oxidation of $\mathrm{TH}_{2}$ by dissolved oxygen is significantly low in yield as comared with that in the oxidation of thiothiamine by dissolved oxygen. Although it has been reported that oxidation of $\mathrm{TH}_{2}$ by active carbon in air gave a good yield (4), it was corrected by Mitsuda et al. (8) 
to be less than 50\%. The cause of a low yield of thiamine formation from $\mathrm{TH}_{2}$ may be the unstability of $\mathrm{TH}_{2}$. The assumption that $\mathrm{TH}_{2}$ may be a precursor of thiamine biosynthesis in plants is unplausible, since $\mathrm{TH}_{2}$ is more easily degraded than is converted to thiamine as reported by the authors (10). Thiothiamine seems to be a more plausible precursor of thiamine biosynthesis.

\section{SUMMARY}

1. Degradation of $\psi$-dihydrothiamine at $35^{\circ}$ in aqueous solution was successively investigated. It was shown to be stable in alkaline solution, but it rapidly degraded in acid solution, being partially converted to thiamine.

2. Addition of hydrogen peroxide to either $n$ - or $\psi$-dihydrothiamine in acid solution resulted in 2-methyl-4-amino-5-aminomethylpyrimidine sulfate formation.

3. Dihydrothiamine was partially converted to thiamine by addition of cyanide in a weakly acid solution. Thiocyanate showed no effect. For the reaction a large amount of cyanide as compared with dihydrothiamine was required and the dissolved oxygen accelerated the reaction, whereas hydrogen or nitrogen inhibited the reaction. These findings suggest that the reaction is a kind of air oxidation catalyzed by cyanide.

\section{ACKNOWLEDGEMENT}

The authors wish to thank Miss H. Hoshino for her kind assistance throughout the experiments.

\section{REFERENCES}

1. Kawasaki, C., Okada, K., and Ono, Y., Vitamins, 26, 303 (1962).

2. Kawasaki, C. and Okada, K., ibid. 16, 61 (1959).

3. Okada, K., ibid. 19, 249 (1960).

4. Hirano, H., Yonemoto, H. and Hara, Y., Chem. Pharm. Bull. 7, 545 (1959).

5. Utsumi, I., Nihon Kagakukaishi 74, 32 (1953).

6. Matsukawa, T., Iwatsu, T., Yakugaku Zasshi, 71, 1215 (1951).

7. Kawasaki, C., Suhara, T. and Horio, T., ibid, 78, 65 (1958).

8. Mitsuda, H., Kawai, F. and Hashitani, Y., J. Vitaminol, 7, 67 (1961).

9. Matsukawa, T., Vitamins 16, 166 (1959); Uehara, K., Murase, J., Hirota, K., and Shirafuji, E., ibid, 26, 43, 48 (1962).

10. Okada, K., ibid, 23, 125, 130134 (1961); Kawasaki, C., ibid, 25, 330 (1962). 